\title{
TRANSEXUAIS E O DIREITO A IDENTIDADE DE GENERO: A INTERLOCUÇÃO ENTRE OS PRINCÍPIOS DA DIGNIDADE DA PESSOA HUMANA, DA IGUALDADE E DA LIBERDADE
}

\author{
Aline Passos Maia ${ }^{1}$ \\ Lara Pinheiro Bezerra ${ }^{2}$
}

\section{Resumo}

Este artigo examina o conceito de gênero, sexo e orientação sexual. Investiga como a pessoa humana transexual se reconhece entre as fronteiras socialmente construídas de sexo e de gênero. Analisa o conceito de identidade e, neste aspecto, centra seu exame na identidade de gênero das pessoas transexuais. Partindo-se dessas premissas, a pesquisa investiga as seguintes questões: a) uma pessoa pode ser reconhecida socialmente ao manifestar o gênero pelo qual se reconhece, ainda que divergente do seu sexo biológico? b) é possível o reconhecimento da alteração do nome e do sexo no registro civil das pessoas transexuais, independentemente da cirurgia de transgenitalização? Nesta perspectiva, estuda-se a relação dialética entre os princípios da dignidade da pessoa humana, da igualdade e da liberdade, com ênfase nas pessoas transexuais. Analisa-se a interpretação dos Tribunais e Cortes Superiores, no que se refere ao reconhecimento da identidade das pessoas transexuais. A metodologia da pesquisa é pura quanto ao tipo e qualitativa quanto à abordagem, de caráter descritivo e exploratório. A coleta de dados da pesquisa é bibliográfica e documental. Como resultado, constatou-se o entendimento dos Tribunais e das Cortes Superiores no sentido de reconhecer a identidade de gênero das pessoas transexuais.

Palavras-chave: Transexualidade. Princípios constitucionais. Direitos fundamentais. O direito à identidade do transexual. Interpretação dos tribunais brasileiros.

\section{INTRODUÇÃO}

Desde muito cedo são apresentados padrões de comportamentos diferentes para homens e mulheres. A sociedade busca, intencionalmente, por meio de diversas estratégias e técnicas, estabelecer uma identidade masculina ou feminina como padrão. Um homem ou uma mulher deverão ser heterossexuais e são incentivados a

\footnotetext{
${ }^{1}$ Doutora em Direito do Trabalho pela Universidad de Salamanca (2014). Professora da Universidade de Fortaleza-UNIFOR. Email: alinepmaia@unifor.br

${ }^{2}$ Mestranda em Direito Constitucional nas Relações Privadas pela Universidade de Fortaleza (UNIFOR). Integrante do Núcleo de Estudos em Direito do Trabalho e Seguridade Social (NEDTS) do Programa de Pós-Graduação da Universidade de Fortaleza. Professora do curso de Graduação em Direito da Universidade de Fortaleza (UNIFOR) - ( Professora Substituta), do Programa de Pós-Graduação em Direito e Processo do Trabalho e Direito Previdenciário da Faculdade Estácio FIC (Professora visitante). Email: larapbezerra@yahoo.com.br
} 
isso. O estímulo da heterossexualidade é acompanhado pela rejeição da homossexualidade, como se a homossexualidade fosse uma doença contagiosa, criando-se, a partir dessa noção, resistência e segregação tanto por aqueles que querem se afastar das pessoas homossexuais como pelas próprias pessoas homossexuais ${ }^{3}$.

O termo gênero remete ao conjunto das representações culturais construídas a partir da diferenciação biológica dos sexos. No conceito de gênero tem-se como premissa o desenvolvimento das noções de masculino e feminino como construção social. Já o termo sexo, pode-se dizer que corresponde ao atributo anatômico, "referese às diferenças anatômicas entre homens e mulheres, a corpos marcadamente diferenciados e ao que nos divide e não ao que nos une". (WEEKS, 2000, online).

Não obstante a definição de "homem" ou "mulher" tenha surgido a partir de uma divisão biológica, um indivíduo pode ter outras identidades que refletem diferentes representações de gênero e que não se encaixam nas categorias padronizadas ${ }^{4}$. Partindo deste contexto, imagine-se o ser humano experimentar a condição de nascer com cromossomos, hormônios, genitais e órgãos reprodutivos internos, mas não se identificar com o seu corpo e, internamente, ter a consciência de pertencer ao gênero oposto.

O distanciamento entre a mente e o corpo resulta do fato de a pessoa não reconhecer a sua imagem diante do espelho e da sociedade, rejeitar o seu fenótipo e não se enquadrar plenamente nas molduras socialmente construídas de sexo e de gênero ${ }^{5}$. Significa, pois, não ser cisgênero ${ }^{6}$. O transexual experimenta essa condição ${ }^{7}$.

Um homem transexual, embora tenha nascido com corpo feminino, sente que seu gênero se assenta, se identifica com o sexo masculino, oposto ao seu sexo biológico. Por outro lado, uma mulher transexual, nascida com corpo masculino, tem a percepção de que o seu gênero se amolda ao sexo feminino.

\footnotetext{
${ }^{3}$ A filósofa Judith Butler, pós-estruturalista estadunidense, busca problematizar a ordem estabelecida em nossa sociedade que exige a coerência total entre um sexo, um gênero e um desejo necessariamente heterossexuais. Pretende desconstruir a ideia de que a matriz heterossexual se sustenta por dois sexos fixos e coerentes, os quais se opõem como todas as oposições binárias do pensamento ocidental: macho x fêmea, homem x mulher, masculino x feminino. Uma das mais importantes contribuições da filósofa se refere ao desenvolvimento da teoria queer, teoria sobre o gênero que defende a orientação sexual e a identidade sexual ou de gênero dos indivíduos como resultado de um constructo social e que, portanto, não existem papéis sexuais essencial ou biologicamente inscritos na natureza humana.

4 “[...] a sociedade em que vivemos dissemina a crença de que os órgãos genitais definem se uma pessoa é homem ou mulher. Porém, essa construção do sexo não é um fato biológico, é social. [...] Sexo é biológico, gênero é social. E o gênero vai além do sexo: O que importa, na definição do que é ser homem ou mulher, não são os cromossomos ou a conformação genital, mas a autopercepção e a forma como a pessoa se expressa socialmente". (JESUS, 2012, online).

5 “[...] a sociedade busca, intencionalmente, através de múltiplas estratégias e táticas, 'fixar' uma identidade masculina ou feminina 'normal' e duradoura. Esse intento articula, então, as identidades de gênero 'normais' a um único modelo de identidade sexual: a identidade heterossexual". (LOURO, 2000, online).

${ }^{6}$ Referem- se as pessoas que se enquadram nas molduras socialmente construídas de sexo e de gênero. Em outras palavras, relacionam-se as pessoas que se encaixam na construção permanente e binária masculino-feminino, no pensamento dicotômico e polarizado sobre os gêneros e na concepção de homem e mulher como polos opostos que se relacionam dentro de um modelo invariável e imutável de domínio e submissão.

${ }^{7}$ As pessoas transexuais são consideradas, coletivamente, como parte do grupo chamado de "transgênero".
} 
A afirmação da identidade sexual compreende as "formas como os sujeitos vivem sua sexualidade", com parceiros/as do mesmo sexo, do sexo oposto, de ambos os sexos ou sem parceiros/as", como lembra Guacira Lopes Louro (2003, p.26) ${ }^{9}$. Assegura a possibilidade de o indivíduo expressar todos os atributos e características do gênero a que pertence e está intrinsecamente relacionada à dignidade da pessoa humana, somada a outros princípios igualmente importantes, a exemplo dos princípios da liberdade e da igualdade.

A transexualidade, portanto, revela o desejo de viver e de ser aceito enquanto pessoa do gênero oposto. $\mathrm{O}$ sentimento de mal estar ou de incompreensão do seu próprio corpo divergente de sua mente resulta, na maioria dos casos, no sentimento do indivíduo de se submeter à cirurgia de redesignação sexual ou a um tratamento hormonal com a finalidade de tornar seu corpo o mais próximo quanto possível do sexo pretendido.

Neste contexto, o presente artigo tem a finalidade de examinar se é possível uma pessoa ser reconhecida socialmente ao manifestar o gênero pelo qual se reconhece, ainda que divergente do seu sexo biológico. Já se pode antecipar que os transexuais são pessoas que possuem o mesmo valor intrínseco que qualquer outro ser humano e, por essa razão, merecem ser tratados pelo Estado e pelos demais membros da sociedade com respeito e dignidade, sendo reconhecidos com a identidade de gênero ${ }^{10}$ pela qual se identificam.

O tema chega às universidades, que passam a reconhecer o nome social de seus alunos (TRANSEXUAIS..., 2016, online), a cirurgia de transgenitalização já é uma realidade na lista de procedimentos custeados pelo Sistema Único de Saúde e, num momento histórico para a televisão, uma artista transexual é indicada ao Emmy. (NATARELLI, 2014, online).

Não é o órgão genital que determina as expressões, os gestos, os movimentos e a veste adequada da pessoa. Existem vários outros elementos identificadores do sexo, motivo pelo qual a definição do gênero não pode mais ser restrita apenas ao sexo aparente. É necessário considerar um conjunto de fatores, tanto psicológicos quanto biológicos e culturais ${ }^{11}$.

\footnotetext{
${ }^{8}$ A sexualidade pode ser compreendida, como adverte Weeks (2000, online), "como uma descrição geral para a série de crenças, comportamentos, relações e identidades socialmente construídas e historicamente modeladas".

${ }^{9}$ Nesse sentido, a identidade sexual é uma construção instável, volúvel e inconstante, uma relação social contraditória e não acabada. "Na medida em que várias identidades - gays, lésbicas, queers, bissexuais, transexuais, travestis — emergem publicamente, elas também acabam por evidenciar, de forma muito concreta, a instabilidade e a fluidez das identidades sexuais". (LOURO, 2000, online).

${ }^{10}$ Os sujeitos se identificam, social e historicamente, como masculinos ou femininos e assim constroem suas identidades de gênero. As identidades sexuais e de gênero se relacionam profundamente, entretanto, elas não são a mesma coisa. Sujeitos masculinos ou femininos podem ser heterossexuais, homossexuais, bissexuais e, ao mesmo tempo, podem ser negros, brancos, ou índios, ricos ou pobres etc. O que importa considerar é que essas identidades são sempre construídas, elas não são dadas ou acabadas num determinado momento. Não é possível estabelecer um momento — nascimento, adolescência ou maturidade — que se considere como aquele em que a identidade sexual e/ou a identidade de gênero seja estabelecida. As identidades estão sempre se constituindo, elas são instáveis e, por conseguinte, passíveis de transformação. (LOURO, 2003, p. 27).

${ }^{11}$ A filósofa estadunidense Judith Butler, professora da Universidade de Berkeley, desconstrói o binarismo gênero/sexo segundo se afirma que o gênero é social enquanto o sexo é o natural. Para a filósofa, o sexo, assim como o gênero, é discursivamente produzido e inscrito num conjunto de práticas, moralidades e significados. Nesse contexto, a separação entre sexo e gênero é abandonada e dá
} 
A incongruência entre o gênero pelo qual a pessoa se expressa e o seu sexo biológico também deságua no Judiciário, mais especificamente, quanto às discussões relativas à possibilidade de reconhecimento da alteração do nome e designativo do sexo no registro civil das pessoas transexuais e reclama do intérprete/aplicador da lei uma postura ativa na interpretação da norma para que a pessoa transexual seja defendida em toda a sua extensão, conforme os princípios constitucionais e direitos fundamentais. Partindo desse contexto, o artigo investiga se é possível o reconhecimento da alteração do nome e do sexo no registro civil dos transexuais, adequando-se a identidade sexual, independentemente da cirurgia de transgenitalização.

Cabe ao presente artigo identificar, inicialmente, a diferenciação entre sexo, gênero e orientação sexual. Em seguida, examinar como o transexual se reconhece entre as fronteiras socialmente construídas de sexo e gênero. $\mathrm{O}$ estudo também perpassa o estudo do conceito de identidade, considerando nesse aspecto o surgimento de novas identidades.

Partindo dessas premissas, o artigo centra seu exame na identidade de gênero das pessoas transexuais e, consequentemente, na imperiosa necessidade de resguardar os princípios constitucionais e de assegurar a concretização dos direitos fundamentais do ser humano transexual, permitindo o reconhecimento de sua identidade para além dos contornos legislativos e conforme a ordem axiologicamente estabelecida no texto constitucional.

Para a análise do problema posto em discussão, observa-se a tendência dos Tribunais quanto ao reconhecimento da identidade sexual das pessoas transexuais, com enfoque na alteração do nome e sexo nos documentos dessas pessoas com a finalidade de adequar a sua identidade de sexo à sua identidade de gênero. Portanto, para a elaboração do artigo, desenvolveu-se pesquisa bibliográfica, de natureza qualitativa e com fins exploratórios e descritivos.

\section{O DISTANCIAMENTO ENTRE A MENTE E O CORPO: DESVENDANDO OS CONCEITOS DE SEXO, GÊNERO E ORIENTAÇÃO SEXUAL}

Alguns dicionários apresentam diferentes conceitos de sexo e de gênero, enquanto outros não fazem diferenciação. Um dos mais conceituados dicionários da língua portuguesa, Aurélio (2017, online), atribui diferente sentido às palavras sexo e gênero, ao estabelecer que sexo é a "Diferença física ou conformação especial que distingue o macho da fêmea" e gênero é o "Grupo de espécies que entre si têm certas analogias".

A Organização Mundial da Saúde afirma que sexo "refere-se às características biológicas e fisiológicas

lugar a uma noção de sexo/gênero inseridos materialmente no corpo, enquanto construções discursivas em relação com os movimentos do poder. (D'ANGELO, 2016, online). 
que definem homens e mulheres e que homem e mulher são categorias sexuais" (BROOKE, 2012). O conceito de gênero da Organização Mundial da Saúde corresponde aos comportamentos, aos papéis, às atividades e às atribuições socialmente construídas e que uma sociedade determinada considera adequados para homens e para mulheres, sendo a diferenciação sexual masculino e feminino categorias de gênero. (MAGAR, 2015, online).

O conceito de sexo contempla as características corporais, como cromossomos, hormônios, genitais e órgãos reprodutivos internos que definem homens e mulheres ao nascer. Corresponde a "um termo descritivo para as diferenças anatômicas básicas, internas e externas ao corpo, diferenciando homens e mulheres (WEEK, 2000, online).

Por outro lado, o conceito de gênero tanto pode se referir a distinção social, com fundamento no sexo do indivíduo, como a distinção psicológica, com base na identificação pessoal do próprio gênero, conforme uma consciência interna. Nas palavras de Scott (1995, p.75), gênero corresponde a uma categoria imposta socialmente sobre um corpo sexuado:

O gênero se torna, aliás, uma maneira de indicar as 'construções sociais' - a criação inteiramente social das ideias sobre os papéis próprios aos homens e às mulheres. É uma maneira de se referir às origens exclusivamente sociais das identidades subjetivas dos homens e das mulheres. O gênero é, segundo essa definição, uma categoria social imposta sobre um corpo sexuado.

Guacira Lopes Louro (2003, p.24) expressa a ideia de "gênero como constituinte da identidade dos sujeitos". A autora compreende "[...] os sujeitos como tendo identidades plurais, múltiplas; identidades que se transformam, que não são fixas ou permanentes, que podem, até mesmo, ser contraditórias". Por fim, arremata a professora que

[...] Ao afirmar que o gênero institui a identidade do sujeito (assim como a etnia, a classe, ou a nacionalidade, por exemplo) pretende-se referir, portanto, a algo que transcende o mero desempenho de papéis, a idéia é perceber o gênero fazendo parte do sujeito, constituindo-o. (LOURO, 2003, p.25).

A filósofa Judith Butler (2003) desconstruiu o conceito de gênero cerne da política feminista, que adota como pressuposto a ideia de que o sexo é natural e o gênero é socialmente construído. $\mathrm{O}$ conceito de gênero como culturalmente construído, diferentemente do de sexo, como naturalmente adquirido, formaram o par sobre o qual as teorias feministas se fundamentaram até meados da década de 1980, quando começaram a ser questionadas, servindo ainda nos dias atuais para justificar preconceitos.

Atualmente as categorias sociais se multiplicam, ultrapassam fronteiras e, para aqueles que se prendem a dicotomias e demarcações bem definidas, essa pluralidade abre várias possibilidades de configurações de gênero e sexo.

Butler (2003, p.25) afirma que: "talvez o sexo sempre tenha sido o gênero, de tal forma que a distinção entre sexo e gênero revela-se absolutamente nenhuma”. A autora (2003, p.25) destaca que o sexo não é natural, 
sendo ele também discursivo e cultural como o gênero. Para a filósofa (2003, p. 29), o gênero seria "um fenômeno inconstante e contextual, que não denota um ser substantivo, mas um ponto relativo de convergência entre conjuntos específicos de relações, cultural e historicamente convergentes”. Ao conceituar gênero, Judith Butler (2004, p.42) descreve:

Gênero não é exatamente o que alguém 'ě', nem é precisamente o que alguém 'possui'. Gênero é o aparato através do qual a produção e a normalização de masculino e feminino tem lugar juntamente às formas intersticiais hormonais, cromossômicas, físicas e performativas que o gênero assume. Assumir que gênero sempre e exclusivamente significa a matrix do 'masculino' e do 'feminino' é precisamente perder o ponto crítico de que esta reprodução binária é contingente, que possui um custo, que as permutações do gênero que não se enquadram no padrão binário são tão válidas quanto as instâncias mais normativas. Amalgamar a definição de gênero com a sua expressão normativa é reconsolidar inadvertidamente o poder que a norma tem de constranger a definição de gênero. Gênero é o mecanismo através do qual as noções de masculino e feminino são construídas e naturalizadas, mas também pode, muito bem, servir como o aparato necessário para a desconstrução e desnaturalização dos referidos termos. (Texto traduzido do original)

Dessume-se do pensamento da autora que o gênero é um ato intencional construído ao longo dos anos, não devendo ser interpretado como um atributo fixo de uma pessoa, mas como uma variável fluida, marcada por diferentes configurações. Outrossim, conforme Butler (2003), o conceito de performatividade, a ideia de que o gênero não é algo que nós somos, mas sim algo que constantemente fazemos, deu margem à proliferação de configurações culturais de sexo e gênero, confundindo o binarismo do sexo.

A identidade de gênero refere-se ao senso interno, pessoal de ser um homem ou uma mulher, um menino ou uma menina. (GLAAD, 2015). É a maneira como a pessoa se enxerga ou se autodetermina, independentemente do sexo, ou seja, como homem, como mulher, como ambos ou mesmo como nenhum dos dois gêneros, independentemente da anatomia. A identidade de gênero, portanto, relaciona-se à maneira de se perceber, de se notar e de compreender a masculinidade ou feminilidade. Louro (2000, online) destaca que:

Reconhecer-se numa identidade, supõe, pois, responder afirmativamente a uma interpelação e estabelecer um sentido de pertencimento a um grupo social de referência. Nada há de simples ou de estável nisso tudo, pois essas múltiplas identidades podem cobrar, ao mesmo tempo, lealdades distintas, divergentes ou até contraditórias. Somos sujeitos de muitas identidades. Essas múltiplas identidades sociais podem ser, também, provisoriamente atraentes e, depois, nos parecerem descartáveis; elas podem ser, então, rejeitadas e abandonadas. Somos sujeitos de identidades transitórias e contingentes. Portanto, as identidades sexuais e de gênero (como todas as identidades sociais) têm o caráter fragmentado, instável, histórico e plural, afirmado pelos teóricos e teóricas culturais.

No que diz respeito aos tipos de orientação sexual, verifica-se o desejo ou a conduta sexual de um indivíduo por determinado gênero, mostra-se para que direção sua sexualidade ${ }^{12}$ está orientada, indica-se por quem a pessoa sente atração, mostra-se a inclinação da pessoa sob o aspecto afetivo, amoroso e sexual.

\footnotetext{
${ }^{12}$ Nas palavras de Louro (2007, p. 18) “a construção dos gêneros e das sexualidades dá-se através de inúmeras aprendizagens e práticas, insinua-se nas mais distintas situaçoes [...].É um processo minucioso, sutil, sempre inacabado”.
} 
A sexualidade tem um universo de significação que compreende uma série de descobertas, uma combinação de informações, orientações e sensações que se desenvolve numa sociedade composta por regras e que constituem os parâmetros fundamentais ao comportamento sexual das pessoas. Esse contexto, portanto, se insere dentro de um processo social que passa pelos interesses dos grupos organizados socialmente e das classes sociais. Para Louro (2000, online):

sexualidade não é apenas uma questão pessoal, mas é social e política. [...] a sexualidade é 'aprendida', ou melhor, é construída, ao longo de toda a vida, de muitos modos, por todos os sujeitos'. [...] a sexualidade envolve rituais, linguagens, fantasias, representações, símbolos, convenções... Processos profundamente culturais e plurais. Nessa perspectiva, nada há de exclusivamente 'natural' nesse terreno, a começar pela própria concepção de corpo, ou mesmo de natureza. Através de processos culturais, definimos o que é - ou não - natural; produzimos e transformamos a natureza e a biologia e, consequentemente, as tornamos históricas. Os corpos ganham sentido socialmente. A inscrição dos gêneros - feminino ou masculino - nos corpos é feita, sempre, no contexto de uma determinada cultura e, portanto, com as marcas dessa cultura. As possibilidades da sexualidade - das formas de expressar os desejos e prazeres - também são sempre socialmente estabelecidas e codificadas. As identidades de gênero e sexuais são, portanto, compostas e definidas por relações sociais, elas são moldadas pelas redes de poder de uma sociedade.

Nesse contexto, insere-se a heterossexualidade, caracterizada pela atração sexual e emocional direcionada ao indivíduo do gênero oposto, a homossexualidade, compreendida pela atração sexual e afetiva dirigida ao ser humano do mesmo gênero e a bissexualidade, correspondente à atração sexual e sentimental orientada para pessoas de ambos os gêneros, mas que estão satisfeitas com o sexo refletido pelo seu corpo. Mas, afinal, o que é transexualidade?

O termo transexualidade ${ }^{13}$ não está relacionado à orientação sexual da pessoa, e sim à sua identidade de gênero, quando determinadas pessoas passam a manifestar os gêneros pelos quais se reconhecem, ainda que divergentes do sexo biológico, como é o caso dos transexuais e demais transgêneros. Uma pessoa transexual elege uma identidade ou expressão de gênero diferente da atribuída ao nascer. Embora, às vezes, a forma anatômica de relacionamento sexual seja a mesma, a transexualidade difere da homossexualidade, da heterossexualidade, da bissexualidade e da travestilidade ${ }^{14}$.

As pessoas transexuais podem ser heterossexuais, homossexuais ou bissexuais, de acordo com o gênero que adotem e do gênero pelo qual se sintam atraídas afetiva e sexualmente. Assim, mulheres transexuais que se

\footnotetext{
${ }^{13}$ A transexualidade se fundamenta na discordância entre o sexo biológico e o gênero pelo qual uma pessoa deseja ser socialmente reconhecida.

${ }^{14}$ Para Jesus (2012, p. 24) o termo travesti refere-se a pessoas que, nascidas com o sexo biológico masculino, vivenciam papéis de gênero feminino, embora não se identifiquem plenamente com o gênero feminino. Assim, ainda que o uso de vestuário do gênero oposto ao seu sexo biológico satisfaça uma experiência pertencente àquele gênero, não apresentam vontade de mudança permanente de sexo. O travesti é uma pessoa que se veste com acessórios e roupas do sexo oposto apenas em parte do dia ou com a finalidade de apresentar shows (no caso dos drag queens e drag kings) ou altera seu corpo (num processo conhecido como body modification) porque sente prazer sexual ou emocional fazendo isto. Não obstante, os travestis gostem da fantasia de se comportar como o sexo oposto, eles não se reconhecem do gênero oposto.
} 
atraem por homens são heterossexuais. Do mesmo modo, homens transexuais que se atraem por mulheres são heterossexuais. Já mulheres transexuais, que se atraem por outras mulheres, são homossexuais. Para o Ministro Luís Roberto Barroso: "Ninguém escolhe ser heterossexual, homossexual ou transgênero. É um destino, um fato da natureza"15. Guacira Lopes Louro (2000, online) contribui com essa ideia afirmando que:

[...] Na medida em que várias identidades — gays, lésbicas, queers, bissexuais, transexuais, travestis - emergem publicamente, elas também acabam por evidenciar, de forma muito concreta, a instabilidade e a fluidez das identidades sexuais. E isso é percebido como muito desestabilizador e 'perigoso'. [...] Para os grupos conservadores tudo isso parece muito subversivo e ameaça atingir e perverter, também, conceitos, valores e 'modos de vida' ligados às identidades nacionais, étnicas, religiosas, de classe. [...] Para os grupos que estão comprometidos com a mudança sexual também são colocados desafios, na medida em que essas identidades de oposição acenam para o movimento constante. [...] Os sujeitos deslizam e escapam das classificações em que ansiámos por localizá-los. Multiplicam-se categorias sexuais, borram-se fronteiras e, para aqueles que operam com dicotomias e demarcações bem definidas, essa pluralização e ambigüidade abre um leque demasiadamente amplo de arranjos sociais.

Os termos cisgênero ${ }^{16}$ e transgênero ${ }^{17}$ resultam da compreensão e enquadramento dos grupos de pessoas a partir da interlocução entre sexo e gênero, socialmente construídos. As pessoas cisgênero são aquelas que se enquadram plenamente nas molduras socialmente construídas de sexo e de gênero. Já as pessoas transgênero são aquelas que não se identificam plenamente com o gênero correspondente ao seu sexo biológico. Elas podem expressar que pertencem ao gênero oposto, a ambos ou a nenhum dos dois gêneros. Neste grupo incluem-se os transexuais, pessoas que se identificam com o gênero oposto ao seu sexo biológico.

Um homem transexual sente que o seu gênero é masculino, embora tenha nascido com corpo do sexo feminino, ou seja, foi designado biologicamente mulher ao nascer, mas se identifica com o gênero masculino. Por outro lado, uma mulher transexual sente que o seu gênero é feminino, embora tenha nascido com corpo masculino. A mulher transexual nasce com o corpo divergente de sua identidade de gênero, o que reflete a vontade de mudanças corporais ou mesmo cirúrgicas para adequar sua mente ao seu corpo. A anatomia é incompatível com a percepção pessoal do gênero. Nessa perspectiva, as pessoas transexuais não estariam mudando de sexo, mas apenas corrigindo seu corpo.

\footnotetext{
${ }^{15}$ Nesse sentido, o voto oral do Ministro Luís Roberto Barroso no julgamento do RE 845.779.

${ }^{16}$ Um indivíduo é considerado cisgênero (do latim cis = do mesmo lado) quando sua identidade de gênero está em conformidade com o gênero que the foi atribuído ao nascer, ou seja, quando sua conduta psicossocial, expressa nas atitudes mais comuns do cotidiano, está inteiramente em consonância com o que a sociedade espera de pessoas do seu sexo biológico. Assim, o indivíduo cisgênero é alguém que está adequado ao sistema binário de gêneros.

17 “'Transgênero' não quer dizer um gay (ou lésbica ou bi) 'mais afetado', nem uma patologia mental do indivíduo. Não é tampouco o nome de mais uma identidade gênero-divergente (como travesti, transexual, crossdresser, drag queen, transhomem, etc.) mas um termo 'guarda-chuva', que reúne debaixo de si todas as identidades gênero-divergentes, ou seja, identidades que, de alguma forma e em algum grau, descumprem, violam, ferem e/ou afrontam o dispositivo binário de gênero”. (LANZ, 2014, p.24).
} 
As expressões transexualidade, transexualismo, síndrome de Harry Benjamin ${ }^{18}$, disforia de gênero, transtorno de identidade de gênero ou ainda disforia neurodiscordante de gênero convergem ainda que, equivocadamente, para a condição da pessoa que se identifica psicologicamente como sendo do gênero oposto ao seu sexo. Esta condição gera um desconforto psicológico e emocional à pessoa transexual e, disso resulta, a vontade de transitar de um sexo a outro por meio da cirurgia de redesignação sexual ${ }^{19}$ ou de tratamento hormonal, mas não significa necessariamente que o transexual seja aquela pessoa que passou ou irá passar por todas as cirurgias de redesignação sexual ${ }^{20}$.

A transexualidade refere-se a um desejo de viver e ser aceito enquanto pessoa do sexo oposto. Refere-se ao anseio de reconhecimento de sua identidade ou expressão de gênero diferente da atribuída ao nascer. Este desejo soma-se a um sentimento de mal estar ou de impropriedade do seu próprio corpo e resulta, na maioria dos casos, na vontade de se submeter à cirurgia de transgenitalização (ou de redesignação sexual ou de readequação sexual) $)^{21}$ ou a um tratamento hormonal com o objetivo de tornar seu corpo o mais próximo quanto possível do sexo almejado.

Na versão atual do Código Internacional de Doenças - CID-10, elaborado pela Organização Mundial da Saúde (2016, online), o transexualismo ainda é catalogado como transtorno de identidade de gênero. O mesmo se verifica no Manual Diagnóstico e Estatístico de Transtornos Mentais - DSM-5, produzido pela Associação Americana de Psiquiatria, seguido pelo Ministério da Saúde e pelo Conselho Federal de Medicina brasileiros. No entanto, o Manual Estatístico e Diagnóstico de Saúde Mental utilizado pela Psiquiatria deixou de considerar a transexualidade como transtorno de identidade, com forte carga patológica, e passou a adotar o termo "disforia de gênero", e não mais transtorno de identidade de gênero.

Nota-se, portanto, uma forte inclinação de retirar o transexualismo, catalogado como transtorno de identidade de gênero do cadastro de doenças, assim como aconteceu com o homossexualismo, que deixou de ser doença em 1985, pelo Conselho Federal de Medicina, e em 1990, pela Organização Mundial da Saúde, passando a ser denominada homossexualidade, uma condição humana da pessoa detentora de direitos e obrigações

\footnotetext{
${ }^{18}$ De acordo com a literatura médica, Harry Benjamin, na década de 40, foi o primeiro médico que estudou pessoas transexuais. Entretanto, não havia uma terminologia específica para esta condição. (ATHAYDE, 2001).

${ }^{19}$ A Resolução no 1.955/2010 do Conselho Federal de Medicina estabelece critérios específicos para a realização do referido procedimento cirúrgico. (BRASIL, 2010, online).

${ }_{20}$ Algumas pessoas definem "transexual" como uma pessoa que passou por cirurgia de redesignação sexual, uma definição enganosa, pois não necessariamente uma pessoa cujo sexo psicológico é o oposto do sexo biológico irá passar por todas as cirurgias de redesignação sexual.

${ }^{21}$ Aprovada na Argentina a Lei de identidade de gênero (Ley 26.743/2012 de Identidad de Género), autorizando que travestis e transexuais escolham seu sexo no registro civil, dispondo a normativa que "Se entiende por identidad de género a la vivencia interna e individual del género tal como cada persona la siente, la cual puede corresponder o no con el sexo asignado al momento del nacimiento, incluyendo la vivencia personal del cuerpo. Esto puede involucrar la modificación de la apariencia o la función corporal a través de medios farmacológicos, quirúrgicos o de otra índole, siempre que ello sea libremente escogido. También incluye otras
} 
legalmente previstos, algumas vezes tolhida ao pretender exercer sua dignidade e não raro privada de seus direitos e garantias fundamentais.

A transexualidade não é uma patologia, não é uma enfermidade. Tratar a transexualidade como doença é subjugar indivíduos, é segregar pessoas, negar direitos, e, sobretudo, é estimular o preconceito e a discriminação de uma sociedade enferma, desconectada da realidade. Os estudos sobre gênero evidenciam que a diferenciação sexual masculino e feminino são resultados de padrões sociais construídos. Não é o órgão genital que determina as expressões, os gestos, os movimentos e o vestuário adequado da pessoa humana. Ademais, a transexualidade não é um transtorno mental. Entretanto, existem tratamentos hormonais e cirurgias de readequação sexual que podem contribuir para que a pessoa se identifique melhor com o seu gênero.

A verdade é que não se trata de problema, de uma doença ou de um transtorno, mas de uma condição pessoale, por conseguinte, não há que se falar em cura, mas sim em direito ao reconhecimento ${ }^{22}$. Nesse contexto, recomendam-se atualmente o uso da expressão disforia de gênero, bem como transexualidade para referir-se a pessoa que se reconhece com o gênero oposto ao seu sexo biológico, ou seja, possui anatomia física contrária à identidade sexual psíquica.

\section{A IDENTIDADE DE GÊNERO DAS PESSOAS TRANSEXUAIS}

O sentimento de incompreensão, de inferioridade, de discriminação e de preconceito rotineiramente circunda a vida e os modos de convívio social ${ }^{23}$ das pessoas transexuais. Desde a infância, essas pessoas são hostilizadas na família, na escola ${ }^{24}$, no trabalho ${ }^{25}$ e na sociedade ${ }^{26}$. Normalmente, as pessoas transexuais apresentam conflito entre a identidade de gênero (sexo psicológico) e a identidade de sexo (sexo físiobiológico) e, por isso, exprimem o desejo de pertencimento ao gênero oposto ao seu sexo, e escolhem brinquedos ou

expresiones de género, como la vestimenta, el modo de hablar y los modales.". (ARGENTINA, 2012, online).

${ }^{22}$ No Brasil a questão transexual veio à tona em 1971, quando foi realizada a primeira cirurgia de transgenitalização do transexual Waldir Nogueira, que adotou o nome de Vadirene Nogueira. A cirurgia foi realizada pelo médico e professor da Universidade Federal de São Paulo, o cirurgião Roberto Farina, quando nem mesmo o Conselho Federal de Medicina autorizava tal procedimento (ROVARIS, 2010, p.9).

${ }^{23}$ Algumas pessoas aceitam outras identidades ou práticas sexuais desde que vividas na intimidade e permaneçam em segredo. $\mathrm{O}$ que incomoda é a expressão pública dessas e a adoção de práticas consideradas não-heterossexuais.

${ }^{24}$ Nas palavras de Louro (2000, online), "[...] a sexualidade deverá ser adiada para mais tarde, para depois da escola, para a vida adulta. É preciso manter a "inocência" e a "pureza" das crianças (e, se possível, dos adolescentes), ainda que isso implique no silenciamento e na negação da curiosidade e dos saberes infantis e juvenis sobre as identidades, as fantasias e as práticas sexuais. Aqueles e aquelas que se atrevem a expressar, de forma mais evidente, sua sexualidade são alvo imediato de redobrada vigilância, ficam "marcados" como figuras que se desviam do esperado, por adotarem atitudes ou comportamentos que não são condizentes com o espaço escolar. De algum modo são indivíduos "corrompidos" que fazem o contraponto da criança inocente e pura".

${ }^{25}$ Amcham Brasil (2017, online) descreve os desafios para a inclusão das pessoas transexuais no mercado de trabalho.

${ }^{26}$ Comumente, meninos e meninas aprendem, muito cedo, piadas gestos, piadas, gozações e apelidos para direcionarem àqueles e àquelas que não se amoldam aos padrões de gênero e de sexualidade admitidos na cultura em que vivem. 
brincadeiras do sexo contrário ao seu sexo biológico ${ }^{27}$.

Embora pessoas transexuais possam exprimir esses desejos ainda quando crianças, não significa, necessariamente, que uma criança que expresse essas vontades seja transexual. As brincadeiras de uma menina com um carrinho ou as de um menino com uma boneca, por si só, não são indícios de transexualidade. Há crianças que podem manifestar esses desejos e incertezas com relação ao gênero no qual se inserem, mas que perdem o interesse de pertencimento ao gênero oposto durante a adolescência. A chegada da adolescência e, posteriormente, da vida adulta também não significa mais facilidades às pessoas transexuais.

Um caso exemplificativo é o de Bianca Figueira, Capitã da Marinha, que após 21 anos de serviços prestados foi reformada da Marinha do Brasil por se declarar uma mulher transexual e manifestar decisão em mudar sua anatomia para torná-la condizente com sua condição psíquica. (TARTUCE, 2016, online). Outro exemplo é o de Luiza Coppieters, de 35 anos, que ensinava desde 2009 em Colégio situado em São Paulo, ocasião em que se apresentava como Luiz e era apelidada de "Professor Luizão". No mês de novembro de 2014, a professora assumiu publicamente sua transexualidade e declarou que passaria a se chamar Luiza. O colégio diminuiu as suas aulas e salários, em março de 2015, e a despediu em junho do mesmo ano ${ }^{28}$.

A essência da feminilidade ou da masculinidade ultrapassa o fator biológico ou genético para alcançar a construção da identidade de gênero da pessoa transexual e o direito ao reconhecimento. No atual contexto social, a ideia de identidade está muito além desses fatores, pois a concepção de identidade do indivíduo pós-moderno se caracteriza pela mudança, pela diferença e pela identificação de inúmeras e cambiantes identidades que se sobrepõem à ideia de uma identidade imutável e que autoriza a construção da identidade de novos indivíduos, igualmente importantes, e sujeitos de direitos e obrigações legalmente previstos.

Hall (2004) identifica três concepções de identidade que se relacionam às visões de sujeito que surgiram em diferentes períodos. A primeira, no período Iluminista, exprime uma visão individualista de sujeito, caracterizada por uma identidade centrada num núcleo imutável, em que predomina a capacidade de razão. A segunda, chamada identidade do sujeito sociológico, é marcada pela interferência das relações intersubjetivas, históricas e culturais na formação da identidade do indivíduo, formada pela relação que estabelece com os outros. Com a identidade sociológica, o sujeito é, ao mesmo tempo, individual e social, é parte e é todo. Já a concepção de

\footnotetext{
${ }^{27}$ Em janeiro de 2016, uma criança de 9 anos de idade foi a primeira no Brasil a conseguir o direito à mudança de nome e de gênero para o feminino nos documentos, na cidade de Sorriso, no Mato Grosso. Para o juiz Anderson Candiotto, da 3. . Vara da Comarca de Sorriso, "a sentença foi dada para garantir que a criança, assim como ela se vê na sua individualidade e na sua orientação feminina, seja respeitada e tratada da forma como é, pois, todas às vezes em que ela fosse se apresentar oficialmente com documento, sofreria discriminação e até rejeição. Seria uma pessoa totalmente feminina com nome masculino, o que sempre geraria constrangimento à ela". (FARIAS, 2016, online). No mesmo sentido, em fevereiro de 2016, outra decisão beneficiou uma criança de 5 anos, que conquistou o direito de ser identificada por outro gênero na sua escola, em Salvador, na Bahia. (PALHARES, 2016, online).

${ }^{28}$ Citado nos argumentos do Ministro Luís Roberto Barroso no julgamento do RE 845.779, p.5-6. Disponível em <http://s.conjur.com.br/dl/transexuais-re-845779-voto-barroso.pdf>Acesso em 02 jun 2016.
} 
identidade do sujeito pós-moderno é formada de elementos cambiantes e que alteram a percepção de uma identidade fixa para reconhecer uma identidade formada e transformada continuamente e permitir a construção da identidade de novos sujeitos.

Dessa forma, o sujeito pós-moderno não tem uma identidade fixa, mas sim uma identidade cambiante, influenciada pelas formas como indivíduo é representado ou interpretado nos diferentes sistemas culturais em que está inserido, soltando as amarras das identidades estáveis do passado e abrindo-se à possibilidade de construção da identidade de novos sujeitos, a exemplo da construção de identidade das pessoas transexuais.

Ainda nessa perspectiva, a visão de sujeito assume contornos históricos e não apenas biológicos, e o indivíduo se depara com variadas e cambiantes identidades em contextos distintos, impulsionando suas ações em várias direções. Assim, o indivíduo pós-moderno se caracteriza pela ideia de mutação ${ }^{29}$, de diferença, de inconstância, marcado pela abertura de suas identidades ${ }^{30}$.

De igual modo, as diferentes posições de sujeito que o indivíduo carrega consigo, dotadas de contínuo movimento e transformação e da possibilidade de construção de novas identidades, trazem constantemente influxos ao ordenamento jurídico e deixa clara a necessidade do legislador e do intérprete da norma voltar os olhos à pessoa transexual sob a perspectiva do direito de serem reconhecidas e tratadas socialmente, de acordo com a sua identidade de gênero.

O aplicador deve preterir a interpretação literal das regras sobre a identidade em favor de uma interpretação constitucional, conforme os princípios da dignidade da pessoa humana, da igualdade e da liberdade, e que oferecem sustentáculo ao direito à autodeterminação do indivíduo em construir-se e reconstruir-se continuamente, ou seja, o direito de ser o que é, de fazer suas escolhas e desenvolver a sua personalidade, de acordo com seus desejos, seus valores e seus interesses.

Robert Alexy (1997) adverte que não é somente a aplicação dos princípios que é importante, mas, sobretudo, uma teoria dos princípios adequada ao direito democrático e que possa servir de baliza a essa aplicação de maneira justa. Para tanto, Alexy (1997, p. 173) afirma que: "apenas uma teoria dos princípios pode conferir validez adequada a conteúdos da razão prática incorporados ao sistema jurídico no mais alto grau de hierarquia e como direito positivo de aplicação direta”.

Na lição de Xerez (2012, p.147), a atividade de interpretação não se restringe a uma operação de lógica formal, à medida que compreende, não apenas juízos de realidade, mas também juízos axiológicos em relação àqueles protegidos juridicamente. No mesmo sentido, explica Reale (2005, p.291):

O trabalho do intérprete, longe de reduzir-se a uma passiva adaptação a um texto, representa

\footnotetext{
${ }^{29}$ Nessa perspectiva, o sujeito pós-moderno pode e deve desconfiar das verdades e certezas sobre os corpos e a sexualidade.

${ }^{30}$ Para Suiama (2004, p. 132), "a identidade de cada um não é um dado, mas sim algo construído a partir das relações que se estabelecem nas sociedades humanas”.
} 
um trabalho construtivo de natureza axiológica, não só por se ter de captar o significado do preceito, colacionando-o com outros da lei, mas também porque se deve ter presentes os da mesma espécie existentes em outras leis: a sistemática jurídica, além de ser lógico-formal é também axiológica ou valorativa.

Trata-se, assim, de uma demanda de construção do reconhecimento da identidade de gênero das pessoas transexuais, que perpassa o âmbito de dominação cultural, com o objetivo de modificar determinados padrões de aceitabilidade social que excluem a pessoa diferente e rejeitam aquilo que intitulam de outros, para conquistar a valorização da diferença, permitindo à pessoa humana transexual o reconhecimento de direitos já existentes ou mesmo o reconhecimento de novos direitos originários das diferenças entre os seres humanos, como, por exemplo, o direito à mudança de nome no registro civil, o direito à mudança de gênero nos documentos e o direito ao uso do banheiro adequado à identidade de gênero, diferenciações essas que buscam assegurar, além das aparências, a igualdade.

O direito à identidade resulta da articulação entre o direito à diferença e o direito à igualdade. Significa, pois, o direito de serem reconhecidas e tratadas socialmente conforme sua identidade de gênero, o direito de ser o que é, de fazer suas escolhas e desenvolver sua personalidade. O direito à igualdade como reconhecimento significa combater padrões culturais arraigados que inferiorizam e estigmatizam as pessoas transexuais diminuindo ou negando a essas pessoas seu valor imanente como seres humanos.

\section{O DIÁLOGO ENTRE OS PRINCÍPIOS DA DIGNIDADE DA PESSOA HUMANA, DA IGUALDADE E DA LIBERDADE: ELEMENTOS PARA A CONSTRUÇÃO DA IDENTIDADE DE GÊNERO DOS TRANSEXUAIS}

O princípio fundamental da dignidade da pessoa humana tem destacada relevância na sistematicidade do ordenamento jurídico, à medida que funciona, simultaneamente, como "elemento que confere unidade de sentido e legitimidade a uma determinada ordem constitucional" (SARLET, 2007, p.79). Por outro lado, o Direito, enquanto sistema axiológico, justifica-se especialmente pelo princípio da justiça e pela concretização do princípio da igualdade (CANARIS, 1996, p.22).

A dignidade, atributo da pessoa humana, implica que ninguém pode ser reduzido a um mero instrumento da realização de qualquer fim ou valor do sistema ou, dito de outro modo, ao homem não se pode atribuir valor, devendo ser compreendido como um fim em si mesmo e em função da sua autonomia enquanto ser racional, como deriva da clássica formulação kantiana ${ }^{31}$.

A exigência enunciada por Kant estabelece que todo homem, aliás, todo ser racional, como fim em si

\footnotetext{
31 "Age de tal maneira que uses a humanidade, tanto na tua pessoa como na pessoa de qualquer outro, sempre e simultaneamente, como fim e nunca simplesmente como meio”. (KANT, 1974, p. 229).
} 
mesmo possui um valor não relativo, mas intrínseco, ou seja, a dignidade (ABBGNANO, 2003, p.276-277). O ser humano enquanto ser racional existe como um fim em si mesmo, não podendo ser usado como meio para o exercício arbitrário desta ou daquela vontade, devendo considerar como fim, todas as suas ações, tanto as que dirige a si mesmo, como as que direciona a outros seres racionais.

O legislador, ao erigir a dignidade da pessoa humana a fundamento da República Federativa do Brasil, buscou salientar que o sustentáculo do Estado Democrático de Direito se assenta nesta noção e constitui valor indispensável ao cidadão, portanto, deve ser respeitado pela sociedade e assegurado pelo poder estatal e suas normas, como medida indispensável de reconhecimento da condição humana.

A articulação entre os princípios constitucionais faz deduzir a existência de uma cláusula geral de tutela da pessoa na Constituição Federal de 1988, figurando a dignidade da pessoa humana como seu principal fundamento ao lado de outros princípios igualmente importantes, a exemplo dos princípios da liberdade e da igualdade. O desrespeito à autodeterminação, ao livre desenvolvimento e à identidade torna ineficaz a cláusula geral de tutela da pessoa e representa o esvaziamento do conteúdo jurídico da dignidade da pessoa humana.

Canotilho (2008, p.225) ressalta que a dignidade da pessoa humana significa que "a República é uma organização política que serve o homem, não é o homem que serve os aparelhos político-organizatórios"32. Assim, a pessoa humana é inserida no centro do ordenamento jurídico brasileiro e, como tal, merecedora de proteção, sobretudo nas situações de vulnerabilidade, onde necessita de amparo especial. ${ }^{33}$

Os transexuais são pessoas que possuem o mesmo valor intrínseco que qualquer outro ser humano e, por essa razão, merecem ser tratados pelo Estado e por todos os demais membros da sociedade com respeito e dignidade e devem ser reconhecidos pela identidade de gênero que se identificam.

Recusar a pessoa transexual o direito de ser tratada socialmente, conforme a sua identidade de gênero, afeta não somente o ser humano transexual, estigmatizado desde a primeira infância de doente ou depravado, mas também o grupo social ${ }^{34}$, contribuindo para a preservação do preconceito e a perpetuação de desigualdades e injustiças que acompanham os transexuais. Ademais, a negativa ao transexual do direito a sua identidade de gênero não encontra amparo em qualquer valor constitucionalmente relevante ${ }^{35}$.

A igualdade formal ou igualdade perante a lei significa que ela deve ser aplicada uniformemente, conforme o que preceitua. Interpretar a igualdade perante a lei é compreender que o aplicador da lei deve

\footnotetext{
32 Também Sarlet (2007, p.66) expressa que, com a positivação da dignidade no art. 10, III, a Constituição "reconheceu categoricamente que é o Estado que existe em função da pessoa humana, e não o contrário, já que o ser humano constitui a finalidade precípua, e não meio da atividade estatal".

${ }^{33}$ Segundo Comparato (2008, p. 1), "tudo gira, assim, em torno do homem e de sua eminente posição no mundo".

${ }^{34}$ Todos aqueles que confrontam os códigos sociais, as amarras legislativas, em busca da existência de uma identidade de gênero com o qual se identifique. Refere-se ao grupo de pessoas transexuais que, diariamente, são vítimas de preconceito, sofrem com a exclusão, enfrentam a indisponibilidade de vagas no mercado de trabalho e encontram dificuldade no acesso educacional.
} 
considerar as distinções feitas nas próprias leis ao aplicar seus comandos ao caso concreto, deve adotar as normas vigentes uniformemente a todos aqueles que se encontrem sob sua incidência. Conforme Rios (2002, p. 31-32 e 41):

o imperativo da igualdade exige igual aplicação da mesma lei a todos endereçada. Disto decorre que a norma jurídica deve tratar de modo igual pessoas e situações diversas, uma vez que os destinatários do comando legal são vistos de modo universalizado e abstrato, despidos de suas diferenças e particularidades.

Por outro lado, a igualdade na lei expressa que, no momento de elaboração da norma jurídica, ela não pode conter discriminações injustificadas e desproporcionais ou tratamentos diferenciados baseados em fundamentos que não sejam razoáveis ou destinados a um fim legítimo. Explica Rios (2002, p. 32) que o legislador tem o dever de "considerar as semelhanças e diferenças quando da instituição dos regimes normativos".

Piovesan (2010, p.252), com maestria, esclarece que igualdade pode ser entendida sob um aspecto formal e material, o qual se classifica em três vertentes:

a igualdade formal, reduzida a fórmula, 'todos são iguais perante a lei (que ao seu tempo, foi crucial para abolição de privilégios); b) a igualdade material, correspondente ao ideal de justiça social e distributiva(igualdade orientada pelo critério socioeconômico); c) a igualdade material, correspondente ao ideal de justiça enquanto reconhecimento de identidades (igualdade orientada pelos critérios de gênero, orientação sexual, idade, raça, etnia e outros).

A máxima Aristotélica que diz "igualdade é tratar igualmente os iguais e desigualmente os desiguais, na medida de sua desigualdade" reflete o aspecto eminentemente jurídico da igualdade. Significa que as pessoas devem ser tratadas como iguais ou desiguais pelo Direito e, como consequência, elas têm direitos e obrigações. Na lição de Aristóteles (1997, p.228):

Pensa-se, por exemplo, que justiça é igualdade - e de fato é, 'embora não o seja para todos, mas somente para aqueles que são iguais entre si; também se pensa que a desigualdade pode ser justa, e de fato pode, embora não para todos, mas somente para aqueles que são desiguais entre si...' 'Para pessoas iguais o honroso e justo consiste em ter a parte que lhes cabe, pois nisto consistem a igualdade e a identificação entre pessoas; dar, porém, o desigual a iguais, e o que não é idêntico a pessoas identificadas entre si, é contra a natureza, e nada contrário à natureza é bom'.

Alexy (2011, p.408-409) ensina que a máxima segundo a qual se deve "tratar igualmente os iguais e desigualmente os desiguais" daria origem a duas normas: "Se não há nenhuma razão suficiente para a permissão de um tratamento desigual, então está ordenado um tratamento igual" (norma de tratamento igual) e "Se há uma razão suficiente para ordenar um tratamento desigual, então está ordenado um tratamento desigual" (norma de tratamento desigual).

A Constituição brasileira de 1988 contempla as três dimensões da igualdade. A igualdade formal, com esteio no art. 5, caput, estabelece que: "todos são iguais perante a lei, sem distinção de qualquer natureză. Já a

\footnotetext{
${ }^{35}$ Nesse sentido, o voto oral do Ministro Luís Roberto Barroso no julgamento do RE 845.779.
} 
igualdade como redistribuição decorre dos objetivos da República, como "construir uma sociedade livre, justa e solidária" (art. $3^{\circ}, \mathrm{I}$ ) e "erradicar a pobreza e a marginalização e reduzir as desigualdades sociais e regionais" (art. $3^{\circ}$, III). Por fim, a igualdade como reconhecimento tem seu fundamento também nos objetivos fundamentais da Constituição, a saber: "promover o bem de todos, sem preconceitos de origem, raça, sexo, cor, idade e quaisquer outras formas de discriminação" (art. $3^{\circ}, \mathrm{IV}$ ).

A igualdade efetiva representa a articulação entre a igualdade perante a lei, a redistribuição e o reconhecimento. Nessa perspectiva, revela que a igualdade almejada pela norma não se restringe a um tratamento uniforme a todos, sendo necessário observar as particularidades de cada pessoa individualmente diante das desigualdades do caso concreto, dando passagem às diferenças entre os indivíduos ${ }^{36}$, ou seja, pressupõe tratar diferentemente os desiguais, mas uma diferença que não instigue desigualdades, ao contrário, sob a perspectiva do direito ao reconhecimento.

Em termos jurídicos, a igualdade se expressa sob a forma de norma jurídica do tipo princípio ${ }^{37}$. Explica Alexy (2011, p.90-91), que os princípios constituem mandamentos de otimização e "ordenam que algo seja realizado na maior medida possível dentro das possibilidades jurídicas e fáticas existentes”. Por se tratar de um princípio jurídico, a igualdade tem sua aplicação condicionada por outras normas, podendo se aplicar em maior ou menor medida um mandamento de otimização.

A igualdade também se exprime em normas mais específicas do tipo regra. Para Alexy (2011, p.90-91), “as regras contêm determinações no âmbito daquilo que é fática e juridicamente possível” e, nesse sentido, representam mandamentos de determinação. São normas que são sempre satisfeitas ou não, devendo se cumprir exatamente aquilo que ela exige ${ }^{38}$.

Xerez (2012, p.177) explica que a norma jurídica projeta uma moldura ${ }^{39}$ que autoriza diferentes possibilidades de aplicação, aptas a ensejar o surgimento de normas com conteúdos distintos, conforme vários sentidos resultantes da interpretação da norma aplicada. A igualdade, portanto, não é um princípio jurídico meramente formal que estabelece equiparação ou distinção diante da situação de igualdade ou de diferença. A

\footnotetext{
${ }^{36}$ Para Konrad Hesse, "a afirmação de que, em razão das diferenças fáticas entre os seres humanos, a igualdade jurídica sempre faz com que sejam mantidas - e muitas vezes reforçadas - algumas desigualdades fáticas é compatível com a afirmação de que a igualdade jurídica produz igualdade fática, ou seja, de que a criação da igualdade jurídica pode ter como consequência uma igualdade fática. Como em todos os juízos sobre igualdade, é necessário não perder de vista a referência a pessoas individuais e aos diferentes aspectos da igualdade." (HESSE apud ALEXY, 2011, p. 417).

${ }^{37}$ Atchabaian (2006) afirma que o princípio da igualdade é direito fundamental, não podendo ser eliminado de qualquer pessoa sendo indispensável uma justificativa do tratamento desigual e que este exprima garantia de sobrevivência e convivência digna.

${ }^{38} \mathrm{Na}$ lição de Alexy (2011, p.85), a distinção entre regras e princípios é "uma das colunas-mestras do edifício da teoria da fundamentação no âmbito dos direitos fundamentais" e a "chave para a solução de problemas centrais da dogmática dos direitos fundamentais".

${ }^{39}$ A "moldura que é a norma superior combina vinculação e indeterminação do conteúdo da norma inferior, trazendo, como consequência, que o processo de criação do direito carregue, dentro de si, a imperiosa necessidade de interpretação". (MURICY,
} 
igualdade implica o estabelecimento de relações entre seres humanos e situações.

A igualdade como reconhecimento da pessoa transexual significa o respeito a sua identidade e as suas diferenças, de modo a rechaçar as injustiças sociais que lhes atingem, que as fazem detentoras de menor respeito e prestígio social, em virtude de padrões culturais arraigados que as inferiorizam, que as excluem e as rejeitam, perpetuando a dominação cultural, o não reconhecimento ou mesmo o desprezo da pessoa humana transexual.

O direito ao reconhecimento não significa conceder a todos a mesma condição por meio da eliminação dos fatores de distinção, mas sim superar os estereótipos e reconhecer a diferença, sem esquecer a referência à pessoa individual. Para Santos (2001), quando a diferença torna as pessoas inferiores, as pessoas têm o direito de serem iguais e quando a igualdade as descaracteriza, elas têm o direito de serem diferentes.

O tratamento social, conforme a identidade de gênero, é medida que se impõe ao reconhecimento dos transexuais e, assim, à tutela do seu direito a igual respeito e consideração, resultado do princípio da dignidade imanente à condição de pessoa. O combate à discriminação e ao preconceito que assola as pessoas transexuais não é tarefa tão simples, envolve uma transformação cultural e a construção de um mundo envolto de indivíduos capazes de observar as singularidades de cada pessoa diante das desigualdades concretas, dando azo ao direito à diferença e ao direito ao reconhecimento dos transexuais.

O Direito, enquanto sistema axiológico, justifica-se, especialmente, pelo princípio da dignidade da pessoa humana e pela concretização dos princípios da igualdade e da liberdade. Ao referir-se à igualdade, Norberto Bobbio (2000, p.7) assevera que este valor, somado à liberdade, se entrelaça na consideração do homem como pessoa. Neste sentido:

Ambos pertencem à determinação do conceito de pessoa humana, como ser que se distingue ou pretende se distinguir de todos os outros seres vivos. Liberdade indica um estado; igualdade, uma relação. O homem como pessoa deve ser, enquanto indivíduo em sua singularidade, livre; enquanto ser social, deve estar com os demais indivíduos numa relação de igualdade.

$\mathrm{O}$ atual conceito de liberdade não se limita ao significado de autonomia da vontade, estando muito mais relacionado à autodeterminação do indivíduo, à possibilidade de a pessoa humana realizar suas próprias escolhas existenciais e perquirir seus objetivos, de acordo com suas vontades, desde que suas escolhas não afetem os direitos de terceiros.

As situações existenciais, portanto, não podem ser analisadas apenas sob o prisma das regras jurídicas, devendo ceder espaço a uma interpretação constitucional, conforme os princípios da dignidade da pessoa humana, da igualdade e da liberdade. Acerca da interpretação constitucional, explica Xerez (2012, p.169):

A intepretação conforme a constituição significa que, entre os sentidos abarcados pela moldura da norma infraconstitucional devem ser eliminados aqueles que forem

2002, p. 117). 
incompatíveis com as normas constitucionais e que, por outro lado, deve prevalecer o sentido que resulte no maior grau de concretização dos direitos fundamentais. A intepretação conforme a constituição envolve juízos de realidade e juízos axiológicos, que resultarão na atribuição à norma infraconstitucional do sentido que consubstancie, com maior eficácia, a proteção normativa de bens e valores consagrados em âmbito constitucional.

O reconhecimento do direito dos transexuais serem socialmente tratados de acordo com a sua identidade de gênero revela a afirmação da eficácia das normas constitucionais aplicadas ao caso concreto, representa a releitura do direito pelo juiz e a intenção cristalina de rechaçar toda e qualquer restrição aos direitos à igualdade e à liberdade existencial dessas pessoas, merecedoras do direito de se afirmar livremente sem coerção a sua identidade.

O chamado pós-positivismo, que caracteriza o Estado Constitucional atual, exige do julgador uma postura ativa, capaz de compreender as peculiaridades do caso concreto e, por meio das normas gerais e abstratas, encontrar uma solução adequada aos direitos fundamentais e aos dispositivos e princípios constitucionais (DIDIER JR., 2010, p.77-78).

A interpretação da norma jurídica, exclusivamente por meio de juízos de realidade, aponta para o insucesso, conforme adverte Reale (1978, p.255-256): "Interpretar uma lei não é explicar a lei, mas é compreendê-la. Não basta ter o espírito lógico, procurando penetrar nas nuances, nos matizes dos textos legais, porque, muitas vezes, esse trabalho de mera análise formal leva à deturpação do Direito”.

Assim, quando situações fáticas se apresentarem distantes dos comandos estabelecidos pelas regras jurídicas, a exemplo de situações de violação à identidade, caberá ao aplicador do Direito garantir essa atividade interpretativa conforme a Constituição, cuja proposta maior é a justiça e a igualdade. Nesse sentido, o voto oral do Ministro Luís Roberto Barroso, no julgamento do RE 845.779, acerca do direito ao uso de banheiro adequado à identidade de gênero das pessoas transexuais:

Referir-se a um indivíduo como Senhor ou Senhora não restringe, ao menos de modo significativo, direito fundamental algum daquele que está a fazer a referência; ao passo que negar o uso do pronome feminino à pessoa que é objeto da fala e que se identifica com o gênero feminino implica rejeição ao seu próprio modo de vida, a como ela se identifica. Cabe por fim, fazer a ponderação entre o direito de uso de banheiro feminino de acesso ao público por parte de transexual feminina e o direito de privacidade das mulheres (cisgênero). Note-se que o suposto constrangimento às demais mulheres seria limitado, tendo em vista que as situações mais íntimas ocorrem em cabines privativas, de acesso reservado a uma única pessoa. De todo modo, a mera presença de transexual feminina em áreas comuns de banheiro feminino, ainda que gere algum desconforto, não é comparável àquele suportado pela transexual em um banheiro masculino.

Nota-se o relevante papel da jurisprudência no processo de releitura do direito e na afirmação da eficácia das normas constitucionais, pois à medida que o juiz se depara com novas demandas é provocado a desenvolver inovações teóricas para a resolução de tais problemas. Isso não significa, entretanto, o reconhecimento de liberdade ilimitada ao intérprete/aplicador. Como bem ensina Xerez (2012, p.179): “A fundamentação da 
decisão judicial, mediante argumentação racional, permite a avaliação da norma decisória como solução adequada ao litígio, servindo como forma de controle dos atos judiciais e remédio contra o arbítrio".

O direito, portanto, revela-se por meio de normas jurídicas, as quais estabelecem modelos de conduta que devem ser realizadas diante de pressupostos fáticos, com a finalidade de concretização de determinados valores (XEREZ, 2012, p.188). Na lição de Reale (2005, p.65), as dimensões do direito, assim compreendidas o fato, o valor e a norma, coexistem em uma relação dialética e compõem o fenômeno jurídico em uma unidade concreta:

Onde quer que haja um fenômeno jurídico, há, sempre e necessariamente, um fato subjacente (fato econômico, geográfico, demográfico, de ordem técnica etc.); um valor, que confere determinada significação a esse fato, inclinando ou determinando a ação dos homens no sentido de atingir ou preservar certa finalidade ou objetivo; e, finalmente, uma regra ou norma, que representa a relação ou medida que integra um daqueles elementos ao outro, o fato ao valor.

Nesse contexto, à míngua de normas jurídicas que tratem do reconhecimento da identidade de gênero das pessoas transexuais, ou dito de outro modo, a falta de regras que amparem a pessoa transexual, ser humano de identidade cambiante na direção da realização de suas vontades e seus desejos, necessária uma postura ativa do juiz a fim de colmatar as lacunas, resguardar os princípios constitucionais e assegurar a concretização dos direitos fundamentais da pessoa transexual, permitindo a construção de sua identidade sem amarras legislativas, mas, sobretudo, conforme a ordem axiologicamente estabelecida no texto constitucional.

\section{AS DECISÕES DOS TRIBUNAIS A CAMINHO DO RECONHECIMENTO DA IDENTIDADE DE GÊNERO}

O sujeito atual se caracteriza pela ideia de mutação, de diferença, de inconstância, marcado pela abertura de identidades. Não raro, casos envolvendo algum aspecto da identidade chegam às cortes brasileiras. Apresentarse-á, ainda que por amostragem, mostrar algumas situações envolvendo a violação à identidade de gênero das pessoas transexuais e ao entendimento dos tribunais acerca da possibilidade de alteração do nome e da designação sexual no registro civil da pessoa transexual, para adequar o registro civil à identidade social dessas pessoas, sem a necessidade de submissão à cirurgia de transgenitalização (ou de redesignação sexual ou de readequação sexual).

Não se objetiva exaurir a apreciação das decisões dos tribunais a caminho do reconhecimento da identidade de gênero, mas tão somente apontar a interpretação dos tribunais nos julgados e os fundamentos das decisões, de modo a fomentar o debate que circunda o tema e que tem sido alvo de acaloradas discussões acadêmicas, doutrinárias e jurisprudenciais.

O entendimento da jurisprudência caminha para o reconhecimento do direito à identidade das pessoas 
transexuais para além das amarras legislativas, possibilitando a alteração do nome no registro civil de transexual, mesmo sem a realização de procedimento cirúrgico de redesignação de $\operatorname{sexo}^{40}$, muito embora, algumas decisões ainda insistam em apontar na contramão de direção ao reconhecimento desse direito ${ }^{41}$, ao manifestar entendimento vinculado a uma identidade imutável do passado, abstendo-se de reconhecer a identidade cambiante das pessoas transexuais e, ainda, limitando os elementos identificadores do sexo à conformação da genitália do indivíduo ou ao sexo eminentemente biológico.

Em decisões sobre o tema, o Superior Tribunal de Justiça já decidiu pela possibilidade de alteração do nome nos registros civis em várias ocasiões ${ }^{4243}$. Dois casos destacam-se no Supremo Tribunal Federal. Tanto no

40 "Ementa: CONSTITUCIONAL. REGISTRO CIVIL DE NASCIMENTO. ALTERAÇÃO. DESIGNATIVO. SEXO. TRANSEXUAL. NÃO SUBMETIDO À CIRURGIA DE REDESIGNAÇÃO SEXUAL. DIGNIDADE. PESSOA. HUMANA 1. Os direitos e garantias fundamentais são desdobramentos imediatos dos princípios fundamentais, previstos na Magna Carta. $\mathrm{O}$ art. $5^{\circ}, \mathrm{X}$, da Constituição Federal elenca os direitos que compõem a integridade moral que deve ser respeitada assim como as demais características da pessoa. 2. O reconhecimento judicial do direito dos transexuais à alteração de seu prenome e da designação sexual constante de seus assentos de registro civil, conforme o sentimento/entendimento que possuem de si mesmos, ainda que não tenham se submetido à cirurgia de transgenitalização, é um meio de garantir o cumprimento e a efetividade do princípio da dignidade da pessoa humana, da intimidade, da personalidade e da cidadania, além de ser uma forma de integrá-lo à sociedade. 3 . Conclui-se com facilidade que os elementos identificadores do sexo não podem ser limitados à conformação da genitália do indivíduo ou ao sexo eminentemente biológico, pois outros fatores devem ser considerados, como: o psicológico, cultural e social, para a correta caracterização sexual. 4. Recurso conhecido e provido". DISTRITO FEDERAL. Tribunal de Justiça do Distrito Federal. Apelação Cível APC 20130710313876. Diário de Justiça eletrônico, 25 set. 2015.

"Ementa: CONSTITUCIONAL. CIVIL. LEI DE REGISTROS PÚBLICOS. ALTERAÇÃO DE PRENOME. TRANSEXUAL QUE NÃO SE SUBMETEU A CIRURGIA DE TRANSGENITALISMO. DESNECESSIDADE DE ALTERAÇÃO DO SEXO BIOLÓGICO PARA ALTERAÇÃO DO NOME. PRINCÍPIO DA DIGNIDADE DA PESSOA HUMANA. APLICAÇÃO SUBSIDIÁRIA DO ART. 58 DA LRP. RECURSO CONHECIDO E PROVIDO. UNANIMIDADE. [...]2. A finalidade do dispositivo (art.58 da LRP) é proteger o indivíduo de constrangimento, humilhação e discriminação pelo uso de um nome que o mesmo não se reconhece, este mesmo fim deve guiar a aceitação da mudança de nome conforme pedido pela parte autora. 3. Independente da condição física da pessoa, é possível a retificação do nome no registro civil sem precitada cirurgia de transgenitalização, desde que comprovado o desejo de ser aceito enquanto pessoa do sexo oposto, nos termos do enunciado 42 (quarenta e dois) da I Jornada de Direito da Saúde do Conselho Nacional de Justiça realizado em 15/05/2014". PARÁ. Tribunal de Justiça do Pará. Apelação Cível N.o 00398675220108140301. Quinta Câmara Cível. Relator: Luzia Nadja Guimarães Nascimento, Julgado em 03 set. 2015. Diário de Justiça eletrônico, 08 set. 2015.

${ }^{41}$ "Ementa: REGISTRO CIVIL. TRANSEXUALIDADE. PEDIDO DE ALTERAÇÃO DE PRENOME E DE SEXO. ALTERAÇÃO DO NOME. POSSIBILIDADE. AVERBAÇÃO À MARGEM. A ALTERAÇÃO DO SEXO SOMENTE SERÁ POSSÍVEL APÓS A CIRURGIA DE TRANSGENITALIZAÇÃO. 1. O fato de a pessoa ser transexual e exteriorizar tal orientação no plano social, vivendo publicamente como mulher, sendo conhecido por apelido, que constitui prenome feminino, justifica a mudança do nome, já que o nome registral é compatível com o sexo masculino. 2. Diante das condições peculiares da pessoa, o seu nome de registro está em descompasso com a identidade social, sendo capaz de levar seu usuário a situação vexatória ou de ridículo, o que justifica plenamente a alteração. 3. Deve ser averbado que houve determinação judicial modificando o registro, sem menção à razão ou ao conteúdo das alterações procedidas, resguardando-se, assim, a publicidade dos registros e a intimidade do requerente. 4. No entanto, é descabida a alteração do registro civil para fazer constar dado não verdadeiro, isto é, que o autor seja do sexo feminino, quando inequivocamente ele é do sexo masculino, pois ostenta órgãos genitais tipicamente masculinos. 5. A definição do sexo é ato médico e o registro civil de nascimento deve espelhar a verdade biológica, somente podendo ser corrigido quando se verifica erro. Recurso desprovido, por maioria”. RIO GRANDE DO SUL. Tribunal de Justiça do Rio Grande do Sul. Apelação Cível No 70064503675. Sétima Câmara Cível. Relator: Sérgio Fernando de Vasconcellos Chaves, Julgado em24 jun. 2015. Diário de Justiça eletrônico, 06 jul. 2015.

${ }^{2}$ "REGISTRO PÚBLICO. MUDANÇA DE SEXO. EXAME DE MATÉRIA CONSTITUCIONAL. IMPOSSIBILIDADE DE EXAME NA VIA DO RECURSO ESPECIAL. AUSÊNCIA DE PREQUESTIONAMENTO. SUMULA No 211/STJ. REGISTRO CIVIL. ALTERAÇÃO DO PRENOME E DO SEXO. DECISÃO JUDiCIAL. AVERBAÇÃO. LIVRO 
Recurso Extraordinário n.o 670.422/RS, quanto no Recurso Extraordinário n. 845.779 foi reconhecida a repercussão geral.

No primeiro caso, as questões suscitadas apresentam nítido conteúdo constitucional - necessidade ou não de cirurgia de transgenitalização para alteração no registro civil, direito à autodeterminação sexual e a possibilidade jurídica ou não de se utilizar o termo transexual no registro civil - e extrapolam o interesse subjetivo das partes, pois além de alcançarem a universalidade de pessoas que buscam adequar sua identidade de sexo à sua identidade de gênero, também repercutem na sociedade.

No Recurso Extraordinário n. 670.422 /RS, discute-se a possibilidade de alteração de gênero no assento de registro civil de transexual, sem a realização do procedimento cirúrgico de redesignação de sexo. Cinge-se a discussão acerca da necessidade de realização de cirurgia de modificação do fenótipo feminino para o masculino, como condição para a alteração do assentamento do sexo no registro civil ${ }^{44}$.

Ao analisar o pedido de retificação de registro civil para troca de prenome e sexo no registro de nascimento, o Juízo da Vara de Registros Públicos e Ações Especiais da Fazenda Pública julgou parcialmente procedente o pleito, para reconhecer a alteração do nome e indeferir a troca do gênero "feminino" para "masculino". Embora o juiz de primeiro grau tenha reconhecido a alteração do nome no registro civil, entendeu ser essencial a realização de cirurgia de redesignação sexual para o deferimento da alteração no assentamento civil relativo ao sexo ${ }^{45}$.

A Oitava Câmara Cível do Tribunal de Justiça do Estado do Rio Grande do Sul, por maioria de votos, deu provimento parcial à apelação, para determinar a averbação, no registro de nascimento da recorrente, da condição de transexual. No entanto, ponderou que, mesmo com os avanços da cirurgia, transexuais ainda não são capazes de adquirir todas as características do sexo oposto ao que nasceram, não possuindo, os órgãos genitais

CARTORÁRIO. [...]. 4. A interpretação conjugada dos arts. 55 e 58 da Lei no 6.015/73 confere amparo legal para que transexual operado obtenha autorização judicial para a alteração de seu prenome, substituindo-o por apelido público e notório pelo qual é conhecido no meio em que vive. 5. Não entender juridicamente possível o pedido formulado na exordial significa postergar o exercício do direito à identidade pessoal e subtrair do indivíduo a prerrogativa de adequar o registro do sexo à sua nova condição física, impedindo, assim, a sua integração na sociedade. 6. No livro cartorário, deve ficar averbado, à margem do registro de prenome e de sexo, que as modificações procedidas decorreram de decisão judicial. 7. Recurso especial conhecido em parte e provido". BRASIL. Superior Tribunal de Justiça - STJ. REsp 737.993/MG. Rel. Ministro João Otávio de Noronha. Quarta Turma, julgado em 10.11.2009. Diário de Justiça eletrônico, 18 dez. 2009.

${ }^{43}$ No mesmo sentido: BRASIL. Superior Tribunal de Justiça - STJ. REsp. 1.008.398. Terceira Turma. Relatora Ministra Nancy Andrighi. Diário de Justiça eletrônico, 18 set. 2009.

${ }^{44}$ Destaca-se a existência de lei alemã regulando o registro dostransexuais desde 10 de setembro de 1980 (Lei dos Transexuais TranssexuellengesetzTSG). Essa norma permite tanto a alteração do prenome do transexual (kleine Lösungpequena solução), quanto a modificação do gênero sexual em seu assento de nascimento, desde que tenha sido submetido à cirurgia de redesignação sexual (groâe L ösung grande solução).

${ }^{45} \mathrm{Na}$ jurisprudência portuguesa, em face de tal situação, tem-se admitido a alteração do registro, desde que verificadas as circunstâncias que a autorizem, pois o registro deve manter-se em conformidade com a nova realidade relativa ao sexo adquirido por quem efetuou a cirurgia de transgenitalização. 
constituídos artificialmente, as mesmas características e funcionalidades dos naturais.

Destacou ser imutável o aspecto cromossômico. Aduziu que a medida pretendida não acarretaria qualquer prejuízo à recorrente, pois, normalmente, utilizam-se documentos de identidade dos quais não consta o gênero do portador, a exemplo da carteira de identidade e do passaporte. (RIO GRANDE DO SUL, 2016, online).

Usualmente, academias, shoppings, empresas, casas de shows e demais espaços coletivos separam os banheiros a partir de uma lógica binária, que reconhece a existência de dois sexos. Identificados socialmente por um gênero diverso do seu sexo biológico, os transgêneros encontram dificuldades para o uso dos banheiros. No segundo caso, Recurso Extraordinário n. ${ }^{\circ}$ 845.779, tem-se o debate sobre o uso de banheiros públicos por transgêneros. A autora aduziu que, apesar de ser transexual, foi impedida por funcionários do shopping center de utilizar o banheiro feminino do estabelecimento, em abordagem vexatória e grosseira.

A sentença a quo julgou procedente o pedido, condenando a ré ao pagamento de indenização por danos morais, no valor de R\$15.000,00 (quinze mil reais). No entanto, a Terceira Câmara Cível do Tribunal de Justiça do Estado de Santa Catarina deu provimento à apelação interposta pela ré e, dentre os fundamentos, entendeu não ser reprovável a conduta da funcionária do estabelecimento que solicitou a recorrente que fizesse uso do banheiro masculino e concluiu não ser indenizável mero incômodo ou aborrecimento.

Esse acórdão foi objeto de recurso extraordinário com repercussão geral reconhecida. ${ }^{46} \mathrm{O}$ julgamento teve início em 19.1 1.2015, tendo sido proferidos os votos dos Ministros Roberto Barroso e Edson Fachin, dando provimento ao recurso, concluso ao relator em 23.11.2016.

Há que se ressaltar também a Ação Direta de Inconstitucionalidade n.o 4275, ainda em trâmite, que pretende a interpretação, conforme a Constituição Federal de 1988, do artigo 58 da Lei 6015/73 - Lei de Registros Públicos ${ }^{47}$. O processo envolve o reconhecimento do direito de transexuais a substituição do prenome e do sexo no registro civil, independentemente da cirurgia de transgenitalização.

O Artigo 58 da Lei de Registros Públicos traz a seguinte redação: "O prenome será definitivo, admitindo-se, todavia, a sua substituição por apelidos públicos notórios”. Ao que parece, a finalidade pretendida pela norma é resguardar a pessoa contra humilhações, constrangimentos e discriminações que possam advir do uso do nome. A Ação Direta de Inconstitucionalidade n. 4275 traz o argumento de que os transexuais possuem

\footnotetext{
46 Repercussão Geral no Recurso Extraordinário n. ${ }^{\circ}$ 845.779/Sc. Disponível em: < http://redir.stf.jus.br/estfvisualizadorpub/jsp/consultarprocessoeletronico/ConsultarProcessoEletronico.jsf?seqobjetoincidente= 4657292> Acesso em: 08 jun. 2016.

${ }^{47}$ O projeto de Lei n. ${ }^{\circ} 6.655 / 06$, aguardando apreciação do Senado, objetiva a alteração do artigo 58 da Lei da Lei no 6.015 , de 31 de dezembro de 1973 - Lei de Registros Públicos, a fim de possibilitar a substituição do prenome das pessoas transexuais. Disponível em: < http://www.camara.gov.br/proposicoesWeb/fichadetramitacao?idProposicao=315120> Acesso em: 08 jun. 2016.
} 
um apelido público notório - o nome social -, pelo qual são identificados pelos amigos e pela família. Sob esse fundamento, a Ação Direta de Inconstitucionalidade n. 4275 contempla a ideia de que a interpretação contida no artigo 58 da Lei de Registros Públicos deve alcançar os transexuais e, para tanto, viabilizar a troca do prenome e sexo das pessoas transexuais, com a finalidade de adequação à sua identidade de gênero.

Os questionamentos trazidos à Ação Direta de Inconstitucionalidade n.o 4275 reforçam a ideia de que o direito à adequação de sexo não pode ser dissociado do direito à adequação do prenome, sendo necessária a adequação do prenome e do sexo das pessoas transexuais no registro civil, independentemente da realização de cirurgia de transgenitalização, pois não é a cirurgia que confere ao indivíduo a condição de transexual, mas sim a convicção de pertencer ao gênero oposto ao sexo biológico.

Assim, a afirmação da identidade sexual, elemento de concretização do princípio da dignidade e reflexo da possibilidade de o indivíduo expressar todos os atributos e características do gênero imanente a cada ser humano, deságua no Judiciário e reclama que o intérprete/aplicador tenha uma postura ativa na interpretação da lei para compreender o nome social das pessoas transexuais como apelidos públicos notórios, conferindo interpretação ao artigo 58 da Lei 6015/73 - Lei de Registros Públicos, conforme a Constituição de 1988, e, nesse sentido, desobrigar a pessoa transexual a manter um nome em descompasso com sua identidade.

A ausência de norma específica no ordenamento jurídico brasileiro destinada a regular a alteração do assento de nascimento em casos de transexualidade, com o objetivo de permitir a mudança do prenome e do sexo da pessoa transexual em seu registro de nascimento, não tem o condão de fazer com que o fato social da transexualidade não contemple solução jurídica. Com maestria, destaca Xerez (2012, p.141):

A análise da relação entre o caso a decidir e o tipo previsto na norma jurídica não se esgota em um juízo lógico formal, tal como ocorreria na subsunção ao conceito. A unidade dos traços que configuram o tipo resulta do valor consagrado pela norma. Dessa forma, a coordenação entre um tipo normativo e o caso a decidir depende não apenas de juízos acerca da realidade, mas também de juízos axiológicos, mediante os quais o julgador valora o caso concreto, com base no valor revelado pelos traços do tipo normativo.

Os textos jurídicos devem ser interpretados mirando a aplicabilidade aos casos concretos, levando-se em conta a generalidade da norma e a singularidade do caso concreto. A norma do caso concreto resulta de um processo construtivo lastreado em normas gerais e elementos da realidade extraídos do caso concreto a ser solucionado. Nesse sentido, explica Xerez (2012, p. 149):

Não é possível a definição do conteúdo da norma do caso concreto exclusivamente a partir da interpretação de normas gerais abstratamente consideradas. A construção da norma do caso concreto depende, necessariamente, da formulação de juízos acerca dos fatos que envolvem o caso a ser solucionado. Dessa forma, norma e realidade encontram-se em interação dialética no processo de interpretação/aplicação da norma jurídica, pelo qual ocorre a densificação normativa, resultando na construção da norma do caso concreto.

Para Larenz (1997, p. 295): "O jurista terá decerto que ter também em conta, no caso de aplicar uma lei já algo envelhecida, se a situação para que esta foi criada ainda subsiste, ou se, porventura, uma alteração da 
situação normativa requer uma interpretação modificada”. Oportuna também a lição de Zagrebelky (2011, p.139):

O caso, para o juiz e para a ciência jurídica, é essencialmente um acontecimento problemático que coloca a questão de como responder a ele, como resolvê-lo em termos jurídicos. Para o direito, portanto, o caso não é algo que deva ser simplesmente registrado, senão algo que deve ser resolvido.

A alteração do registro civil das pessoas transexuais adequando-se o sexo jurídico ao sexo aparente, ou seja, à identidade sexual, reflete a afirmação da dignidade da pessoa humana como epicentro do ordenamento jurídico, tal como consagrado na Constituição brasileira de 1988.

Resulta em afirmação ao princípio da igualdade, na medida em que significa o respeito a sua identidade e a suas diferenças, e também reforça o princípio da liberdade, permitindo à pessoa transexual ser quem ela realmente é, apta a realizar suas próprias escolhas existenciais e a conquistar seus objetivos, de acordo com suas vontades e desejos. Larenz (1997, p.329-330) acentua que:

A tarefa da Jurisprudência no que toca à preparação da legislação é tríplice: em primeiro lugar tem que tornar claros como problemas jurídicos os problemas que se apresentem, com todas as implicações que daí resultarem; em segundo lugar - em conjugação com outras ciências, sobretudo a sociologia empírica do Direito -, tem que elaborar propostas de solução que se ajustem ao Direito vigente e que possibilitem ao legislador alternativas; em terceiro lugar, tem que prestar ajuda à formulação.

A aplicação do Direito não se restringe à subsunção da norma ao fato. Ao contrário disso tudo, o Direito transcende a lei, depende da interpretação, da valoração, da singularidade do caso concreto. $\mathrm{O}$ pensamento orientado a valores surge quando a lei abre caminho para o preenchimento de valores pelo intérprete.

Desse modo, a jurisdição, enquanto atividade criadora do direito, exige a atividade de intepretação, permeada por valores constitucionais, incumbindo ao magistrado aplicar o direito da sua época e justificar racionalmente a adequação dos juízos de realidade e juízos axiológicos, não podendo o juiz somente considerar a vontade da lei, devendo utilizar o critério de valoração como subsídio à interpretação da norma.

\section{CONCLUSÃO}

Este artigo analisou o conceito de sexo, gênero e orientação sexual. Em seguida destacou como o transexual se reconhece entre as fronteiras socialmente construídas de sexo e gênero. O estudo também examinou o conceito de identidade, considerando, nesse aspecto, o surgimento de novas identidades e, em particular, a identidade de gênero da pessoa transexual.

Neste contexto, tem-se como primeira conclusão desta análise que os elementos caracterizadores do gênero não podem ser restritos à conformação da genitália do indivíduo ou ao sexo eminentemente biológico, pois outros fatores devem ser considerados, a exemplo dos fatores psicológico, cultural e social. 
A afirmação da identidade sexual dos transexuais, elemento de concretização do princípio da dignidade da pessoa humana e reflexo da possibilidade de o indivíduo expressar todas as suas características e atributos, chega aos tribunais e reclama do intérprete/aplicador uma postura ativa na interpretação da lei, especialmente no que se refere à discussão acerca da alteração do nome e do designativo do sexo no registro civil, independentemente da realização da cirurgia de redesignação sexual.

O entendimento da jurisprudência caminha para o reconhecimento do direito à identidade das pessoas transexuais para além das amarras legislativas, possibilitando a alteração do nome no registro civil da pessoa transexual, mesmo sem a realização de procedimento cirúrgico de redesignação de sexo, apesar de algumas decisões ainda resistirem ao reconhecimento desse direito, limitando os elementos identificadores do sexo à conformação da genitália do indivíduo ou ao sexo eminentemente biológico.

A recusa à pessoa transexual do direito de ser tratado socialmente, conforme a sua identidade de gênero, significa postergar o exercício do direito a sua identidade pessoal e implica subtrair da pessoa transexual a garantia de cumprimento e de efetividade dos princípios da dignidade da pessoa humana, da liberdade e da igualdade. Essa postura renitente também constitui afronta ao direito à intimidade e ao direito de personalidade da pessoa transexual. Significa, portanto, a contramão na direção dos princípios constitucionais e direitos e garantias fundamentais, imanentes ao Estado Democrático.

A alteração do registro civil das pessoas transexuais reflete o reconhecimento da dignidade da pessoa humana como epicentro do ordenamento jurídico, tal como consagrado na Constituição brasileira de 1988. Resulta na afirmação ao princípio da igualdade, na medida em que significa o respeito a sua identidade e a suas diferenças, e também reforça o princípio da liberdade.

A segunda conclusão desta pesquisa indica que a ausência de norma específica no ordenamento jurídico brasileiro destinada a regular o direito das pessoas transexuais à alteração do nome e do sexo no assento de nascimento, independentemente da cirurgia de transgenitalização, não tem o condão de autorizar que o fato social da transexualidade não contemple solução jurídica.

A jurisdição, enquanto atividade criadora do direito, exige a atividade de intepretação, permeada por valores constitucionais, cabendo ao julgador aplicar o direito da sua época e justificar racionalmente a adequação dos juízos de realidade e juízos axiológicos, não podendo o magistrado considerar somente a vontade da lei, devendo utilizar o critério de valoração como subsídio à interpretação da norma. 


\title{
TRANSSEXUALS AND THE RIGHT TO GENDER IDENTITY: THE DIALOGUE BETWEEN THE PRINCIPLES OF HUMAN DIGNITY, EQUALITY AND FREEDOM
}

\begin{abstract}
This article examines the concept of gender, sex and sexual orientation. It investigates how the transgender human person recognizes himself between the socially constructed frontiers of sex and gender. It analyzes the concept of identity and, in this respect, focuses its examination on the gender identity of transsexual people. Based on these premises, the research investigates the following questions: a) can a person be socially recognized when he manifests the gender by which he recognizes himself, even though he diverges from his biological sex? $\mathrm{b}$ ) is it possible to recognize the change of name and gender in the civil registry of transsexual people, regardless of transgender surgery? In this perspective, the dialectic relationship between the principles of human dignity, equality and freedom, with emphasis on transsexual people, is studied. The interpretation of the Courts and Superior Courts, regarding the recognition of the identity of transsexual people, is analyzed. The methodology of the research is pure as to the type and qualitative regarding the approach, of descriptive and exploratory character. The collection of research data is bibliographical and documentary. As a result, the understanding of the Courts and Superior Courts in order to recognize the gender identity of transsexual people was verified.
\end{abstract}

Keywords: Transsexuality. Constitutional principles. Fundamental rights. The right to the identity of the transsexual. Interpretation of the Brazilian courts.

\section{REFERENCIAS}

ABBGNANO, Nicola. Dicionário de Filosofia. São Paulo: Martins Fontes, 2003.

ALEXY, Robert. El concepto y la validez del derecho. 2. ed. Barcelona: Gedisa, 1997.

ALEXY, Robert. Teoria dos direitos fundamentais. Trad. Virgílio Afonso da Silva. São Paulo: Malheiros, 2011.

ARGENTINA. Ley 26.743/2012 de Identidad de Género. Establécese el derecho a la identidade de género de las personas. Disponível em: < http://www.tgeu.org/sites/default/files/ley_26743.pdf> Acesso em: 11 jun. 2016.

ARISTÓTELES. Política. 3. ed. Brasília: Universidade de Brasília, 1997.

ATHAYDE, Amanda V. Luna de. Transexualismo masculino. Arq Bras Endocrinol Metab., v. 45, n. 4, p. 407-414, ago. 2001.

ATCHABAIAN, S. Princípio da igualdade e ações afirmativas. 2. ed. São Paulo: RCS, 2006.

BOBBIO, Norberto. Igualdade e Liberdade. Rio de Janeiro: Ediouro, 2000.

BRASIL. Constituição (1988). Constituição da República Federativa do Brasil. Brasília, DF, Senado, 1988.

Conselho Federal de Medicina. Resolução CFM no 1.955/2010. Dispõe sobre a cirurgia de transgenitalismo e revoga a Resolução CFM no 1.652/02. Diário Oficial da União, Poder Executivo, Brasília-DF, 
n. 232, 2 dez.2002. Seção 1, p.80-81. Disponível em: < http://www.portalmedico.org.br/resolucoes/CFM/2010/1955_2010.htm> Acesso em: 20 maio 2016. BRASIL. Superior Tribunal de Justiça - STJ. REsp 737.993/MG. Rel. Ministro João Otávio de Noronha. Quarta Turma, julgado em 10.11.2009. Diário de Justiça eletrônico, 18 dez. 2009. Disponível em: < http://stj.jusbrasil.com.br/jurisprudencia/5718884/recurso-especial-resp-1008398-sp-2007-0273360-5> Acesso em: 08 maio 2016.

Superior Tribunal de Justiça - STJ. REsp. 1.008.398. Terceira Turma. Relatora Ministra Nancy Andrighi.

Diário de Justiça eletrônico, 18 set. 2009. Disponível em: < http://stj.jusbrasil.com.br/jurisprudencia/5718884/recurso-especial-resp-1008398-sp-2007-0273360-5> Acesso em: 08 maio 2016.

Câmara dos Deputados. Ação Direta de Inconstitucionalidade n.o 4275. Disponível em: < http://www.camara.gov.br/proposicoesWeb/fichadetramitacao?idProposicao=315120> Acesso em: 08 jun. 2016.

BRASIL, Amcham. Transgênero, transexual e travestis: os desafios para a inclusão do grupo no mercado de trabalho. Blog Ecoando, 10 abr. 2017. Disponível em: < http://economia.estadao.com.br/blogs/ecoando/transgenero-transexual-travesti-os-desafios-para-a-inclusaodo-grupo-no-mercado-de-trabalho/> Acesso em: 20 abr. 2017.

BUTLER, Judith P. Problemas de gênero: feminismo e subversão da identidade. Tradução de Renato Aguiar. Rio de Janeiro: Civilização Brasileira, 2003.

Undoing gender. New York: Routledge, 2004.

BROOKE, Keith. Strange divisions and alien territories: The sub-genres of science fiction. Palgrave Macmillan. 2012.p. 177. Disponível em: <

https://books.google.com.br/books?id=yrQcBQAAQBAJ\&pg=PA177\&redir_esc=y\# ${ }^{*}=$ onepage\& $q \& f=f a l s e>$ Acesso em: 09 jun. 2016.

CANARIS, Claus-Wilhelm. Pensamento sistemático e conceito de sistema na ciência do direito. Lisboa: Fundação Caloustre Gulbenkian, 1996.

CANOTILHO, José Joaquim Gomes. Direito constitucional e teoria da constituição. 7. ed. Coimbra: Almedina, 2008.

CHOERI, Raul Cleber da Silva. O conceito de identidade e redesignação sexual. Rio de Janeiro: Renovar, 2004.

COMPARATO, Fábio Konder. A confirmação histórica dos direitos humanos. 6. ed. São Paulo: Saraiva, 2008.

D' ANGELO, Luisa Bertrami. 7 conceitos essenciais para entender o pensamento de Judith Butler. NotaTerapia, 28 jan. 2016. Disponível em: < http://notaterapia.com.br/2016/01/28/7-conceitos-essenciais-para-entender-opensamento-de-judith-butler/> Acesso em: 10 fev. 2017.

DIAS, Paula Regina Pereira dos Santos Marques; SOARES, Zilmar Timoteo. O sistema especial de proteção dos direitos humanos: a busca pela igualdade e o respeito à diferença. Revista Cesumar, Maringá, v. 16, n. 1, p.41-52, jan./jun. 2014. 
DICIONÁRIO DO AURÉLIO ONLINE. Disponível em: <https://dicionariodoaurelio.com/> Acesso em: 01 jun. 2017.

DIDIER JR., Fredie. Curso de direito processual civil. Salvador: Juspodium, 2010. v. I.

DISTRITO FEDERAL. Tribunal de Justiça do Distrito Federal. Apelação Cível APC 20130710313876. Diário de Justiça eletrônico, 25 set. 2015.

FARIAS, Adriana. Criança de 9 anos é a primeira no Brasil a ser autorizada pela Justiça a mudar de nome e gênero. Veja São Paulo, 29 jan. 2016. Disponível em: < http://vejasp.abril.com.br/materia/crianca-transexual-primeirajustica-nome-genero-mudanca > Acesso em: 30 maio 2016.

FERREIRA FILHO, Manoel Gonçalves. Direitos humanos fundamentais. São Paulo: Saraiva, 1995.

GLAAD Media Reference Guide. Transgender Issues (em inglês). 2015. Disponível em: < http://www.glaad.org/reference/transgender> Acesso em: 09 jun. 2016.

HALL, Stuart. A identidade cultural na pós-modernidade. 9. ed. Rio de Janeiro: DP\&A, 2004.

JESUS, Jaqueline Gomes de. Orientações sobre a população transgênero: conceitos e termos. Brasília: Autor, 2012.

em: <https://www.sertao.ufg.br/up/16/o/ORIENTA\%C3\%87\%C3\%95ES_POPULA\%C3\%87\%C3\%83O_TRA NS.pdf?1334065989> Acesso em: 20 abr. 2017.

KANT, Immanuel. “Fundamentação da Metafísica dos Costumes”. In: Os Pensadores. São Paulo: Abril Cultural, 1974.

LANZ, Letícia. O corpo da roupa: a pessoa transgênera entre a transgressão e a conformidade com as normas de gênero. $\quad$ Curitiba, $\quad 2014.2342 \quad$ f. $\quad$ Disponível $\quad$ em:< http://acervodigital.ufpr.br/bitstream/handle/1884/36800/R\%20-\%20D\%20-

\%20LETICIA\%20LANZ.pdf?sequence=1. > Acesso em: 20 abr. 2017.

LARENZ, Karl. Metodologia da ciência do direito. 3. ed. Lisboa: Calouste Gulbekizan, 1997.

LOURO, Guacira Lopes. Gênero, sexualidade e educação: das afinidades políticas às tensões teóricometodológicas. Educação em Revista. Belo Horizonte. n. 46.p. 201-218. dez. 2007.

Gênero, sexualidade e educação: Uma perspectiva pós-estruturalista. 6. ed. Petropólis: Vozes, 2003. Disponível em: < https://bibliotecaonlinedahisfj.files.wordpress.com/2015/03/genero-sexualidade-eeducacao-guacira-lopes-louro.pdf> Acesso em: 3 mar. 2017.

O corpo educado: pedagogias da sexualidade. Tradução dos artigos: Tomaz Tadeu da Silva. Belo Horizonte: $\quad$ Autêntica, $2000 . \quad$ Disponível em: < https://repositorio.ufsc.br/bitstream/handle/123456789/1230/Guacira-Lopes-Louro-O-Corpo-Educado-pdfrev.pdf?sequence $=1>$ Acesso em: 3 mar. 2017.

MAGAR, Veronica. Gender, health and the Sustainable Development Goals (em inglês). WHO. 2015. Disponível em: < http://www.who.int/gender-equity-rights/news/gender-health-sdgs/en/> Acesso em: 09 jun. 2016. 
MURICY, Marília. Racionalidade do direito, justiça e interpretação. Diálogo entre a teoria pura e a concepção luhmanniana do direito como sistema autopoiético. In: BOUCAULT, Carlos E. de Abreu; RODRIGUEZ, José Rodrigo (Org.). Hermenêutica plural. São Paulo: Martins Fontes, 2002.p. 117.

NATARELLI, Natália. Laverne Cox é a primeira mulher transexual indicada ao Emmy. Exame.com, 10 jul. 2014. Disponível em: <https://www.sertao.ufg.br/up/16/o/orienta\%c3\%87\%c3\%95es_popula\%c3\%87\%c3\%83o_trans.pdf? 133406 5989 > Acesso em: 20 abr. 2017.

ORGANIZAÇÃO MUNDIAL DE SAÚDE. CID 10 - Classificação Internacional de Doenças e Problemas Relacionados à Saúde. Disponível em: < http://cid10.bancodesaude.com.br/cid-10-f/f64/transtornos-daidentidade-sexual> Acesso em: 05 maio 2016.

PALHARES, Isabela. Isabela, de 5 anos, ganha o direito de ser menina. Estadão de São Paulo, 13 fev. 2016. Disponível em: < http://educacao.estadao.com.br/noticias/geral,isabela--de-5-anos--ganha-o-direito-de-sermenina,10000016147> Acesso em: 30 maio 2016.

PIOVESAN, F. Temas de direitos humanos. 4. ed. São Paulo: Saraiva, 2010.

REALE, Miguel. Filosofia do direito.8. ed. São Paulo: Saraiva, 1978. v. I-II. Lições preliminares de direito. 27.ed. São Paulo: Saraiva, 2005.

RIO GRANDE DO SUL. Tribunal de Justiça do Rio Grande do Sul. Apelação Cível No 70064503675. Sétima Câmara Cível. Relator: Sérgio Fernando de Vasconcellos Chaves, Julgado em 24 jun. 2015. Diário de Justiça eletrônico, 06 jul. 2015.

Repercussão Geral no Recurso Extraordinário n. ${ }^{\circ}$ 670.422/RS. Disponível em: < http://redir.stf.jus.br/estfvisualizadorpub/jsp/consultarprocessoeletronico/ConsultarProcessoEletronico.jsf?seq objetoincidente $=4192182>$ Acesso em: 08 jun. 2016.

RIOS, Roger Raupp. O princípio da igualdade e a discriminação por orientação sexual. A homossexualidade no Direito brasileiro e norte-americano. São Paulo: Revista dos Tribunais, 2002.

ROVARIS, Aline. Retificação do registro civil do transexual. 2010. Disponível em: <http:/ / www.bib.unesc.net/biblioteca/sumario/00004E/00004EEF.pdf >. Acesso em: 16. maio 2016.

SANTOS, Boaventura de Souza. As tensões da modernidade. Texto apresentado no Fórum Social Mundial. Porto Alegre, 2001.

SARLET, Ingo. Dignidade da pessoa humana e direitos fundamentais na Constituição Federal de 1988. Porto Alegre: Livraria do Advogado, 2007.

SCOTT, Joan Wallach. Gênero: uma categoria útil de análise histórica. Educação \& realidade, Porto Alegre, v. 20, n. 2, p. 71-99, jul./dez. 1995.

SUIAMA, Sergio Gardenghi. Identidades, diferenças. Boletim cientifico - Escola Superior do Ministério Público da União, Brasília: ESMPU, n. 2, p. 131-139, abr./jun. 2004.

TARTUCE, Flávio. Transexualidade e transexualismo. Disponível em: < 
http://flaviotartuce.jusbrasil.com.br/artigos/142578596/transexualidade-x-transexualismo> Acesso em: 02 jun. 2016.

TRANSEXUAIS poderão incluir nome social em matrícula da PUC-SP por meio da internet. Band.com, 28 jan. 2016. Disponível em: < http://noticias.band.uol.com.br/cidades/noticia/100000791766/trans-poderao-incluirnome-social-em-matricula-da-puc-sp.html> Acesso em: 12 mar. 2017.

WEEKS, J. O corpo e a sexualidade. In: LOURO, G. L. (Org.). O corpo educado: pedagogias da sexualidade. 2. ed. Belo Horizonte: Autêntica, 2000.

XEREZ, Rafael Marcílio. Dimensões da concretização dos direitos fundamentais: Teoria, método, fato e arte. 2012.Tese (Doutorado em Direito). Programa de Pós-Graduação em Direito da Faculdade de Direito da Universidade Federal da Bahia. Salvador, 2012. Disponível em: < https://repositorio.ufba.br/ri/bitstream/ri/15282/1/TeseDoutoradoRafaelXerez.pdf > Acesso em: 10 maio 2016.

ZAGREBELSKY, Gustavo. El derecho dúctil. Tradução de Marina Gáscon. 10. ed. Madri: Trotta, 2011.

Trabalho enviado em 06 de janeiro de 2017.

Aceito em 29 de abril de 2017. 